\title{
ユークリッド変換に不変な特徵量を用いた 二次元大域スキャンマッチング方式
}

\author{
友 納 正 裕*
}

\section{A 2-D Global Scan Matching Method using Euclidean Invariant Signature}

\author{
Masahiro Tomono*
}

\begin{abstract}
This paper presents a new scan matching method for mobile robot localization and mapping. The proposed method utilizes Euclidean invariant features in order to match an input scan with a reference scan using no initial alignment. This method is capable of global scan matching in environments having curved objects. Experimental results show that our method successfully performed map building and global scan matching in a large environment (corridor) and a complex-shape environment (room).
\end{abstract}

Key Words: Mobile Robots, Scan Matching, Global Localization, Map Building, SLAM

\section{1.はじめに}

移動ロボットが安全かつ効率よく目的地まで走行するには, 環 境マップとその上での自己位置推定が不可欠である. 環境マップ を人手で作成するのは多大な工数がかかるため, ロボット自身に マップを構築させることが行われる。、ロボットに搭載したセンサ を用いてマップを構築するには，ロボットの姿勢を知る必要があ る.ところが, ロボットの姿勢を正確に知るにはマップが必要で ある。このように, マップ構築には自己位置推定が切り離せない ため, 両者を同時に行う SLAM (Simultaneous Localization and Mapping）が盛んに研究されている [3] [10] [13] [15]. なお， 本稿では, 口ボットは水平面上を走行するとし, 位置と方位を まとめて姿勢 $(x, y, \theta)$ と呼ぶ.

ロボットの自己位置推定は, 大きく, 姿勢追跡 (pose tracking）と大域自己位置推定（global localization）に分けられる. 姿勢追跡は，一時点前の姿勢から現在姿勢を逐次的に推定する ことを繰り返す方法である．多くの場合，オドメトリで推定し たロボット姿勢を, 外界センサの計測データとランドマークと の照合結果によって修正して, 精度の高いロボット姿勢を得る。 SLAMにおいては，それまでに作ったマップを用いて姿勢追跡 を行い，そのロボット姿勢に基づいて計測データをマップに追 加していくことを繰り返せば, マップを構筑できる。この意味 で, 通常のマップ構築での自己位置推定は, 姿勢追跡に相当す る. 一方, 大域自己位置推定は, ロボットの初期姿勢を与えず に, マップ全域でロボットの姿勢を推定する. 大域自己位置推

原稿受付 2005 年 12 月 $8 \mathrm{H}$

*東洋大学機能ロボティクス学科

* Department of System Robotics, Toyo University
定ができると，何らかの原因で自己位置を見失った状態から自 律的に復帰することが可能になるので, ナビゲーションのロバ スト性を大幅に高めることができる。また，マップ構筑におい ても，同じ場所に戻ったことを検知したり，別々に作ったマッ プを結合する際に, 大域自己位置推定が必要になる.

このようなマップ構築や自己位置推定の有力な手法として, レーザレンジファインダ (LRF) のスキャンマッチングがある. 本稿で考える LRF のスキャンは, LRF の中心から対象物まで の距離を床面に平行な平面上で測定した二次元データであり，点 列で与えられるとする．スキャンマッチングとは，入力スキャ ンと参照スキャンが合致するように両者の相対姿勢 $(x, y, \theta)$ を 求める問題である。参照スキャンは, 他のスキャンでもよいし, 複数のスキャンを重权合わせて構成したマップでもよい.

従来のスキャンマッチング方式の多くは, 入力スキャンと参 照スキャン間の相対姿勢のラフな推定值を与え, それを初期値 としてマッチング誤差を最小化するような相対姿勢を局所的に 探索する.マップ構築や姿勢追跡では，この初期值としてオド メトリ情報を用いることが多い.このようなスキャンマッチン グを局所型と呼ぶことにする．局所型スキャンマッチングとオ ドメトリ情報を併用して, ロボットが走行中に取得したスキャ ンがうまく重なるように次々につなぎ合わせていけば，環境マッ プとロボット軌跡を同時に求めることができる。

一方, 大域自己位置推定を行う場合は, 初期值なしでマップ 全域にマッチングできる方法が必要になる。このようなスキャ ンマッチングを大域型と呼ぶことにする，局所型スキャンマッ チングでも, Monte Carlo Localization [4] などの複数仮説追 跡機構を併用すれば大域自己位置推定は可能であるが, 初期仮 説を一様分布と仮定すると，広い環境では仮説数が膨大になる 
ため，多大な処理コストがかかるという問題がある。大域型ス キャンマッチングができれば，あらかじめ少数の有力仮説に絞 り込めるので, 複数仮説追跡を効率的に行えるという利点があ る. 従来も大域型スキャンマッチング方式はいくつか提案され ているが，対象とする形状が限定されていたり，少数の顕著な 特徵を利用するため, 特徵の誤検出や欠落に弱いという問題が ある。

本稿では，こ机らの問題に対処する大域型の二次元スキャン マッチング方式を提案する，本方式は，大域候補抽出と詳細マッ チングの 2 段階で処理を行う。大域候補抽出では，スキャン点 とそこでの接線方向を合わせて特徵点として用い, 各特徽点に 対してユークリッド变換（並進と回転）に不変な特徵ベクトル を生成する。この特徵べクトルによって各スキャン点が識別性 の高い特徴点として働いて, 大域的なマッチング候補を求める ことができる．詳細マッチングでは，大域候補抽出で得られた 複数の有力候補について，入力スキャンと参照スキャンのずれ が最小となるように最適化を行う。

本稿の貢献は, ユークリッド不变な特徵ベクトルを用いた大 域候補抽出手法と, 複数の有力候補を保持しながら, 各候補の 䛊差を最小化する詳細マッチング手法の提案にある。本方式の 利点は，スキャン点をそのまま使うので特徵の誤検出の抢それ がなく，また，多数のスキャン点のマッチング結果を統計的に 扱うので，データの欠落やノイズに強いことである．また，本 方式はマッチングの探索範囲を狭めることにより, 局所型に近 い形態で利用することも可能であり，マップ構築と大域自己位 置推定の両方に利用可能である.

\section{2. 関 連 研 究}

\section{1 二次元スキャンマッチング}

これまで, 多くの二次元スキャンマッチング方式が提案され, 移動ロボットの自己位置推定やマップ構築に応用されている。 キャンマッチング方式で最も基本的なのは, ICP [1] [18] であ る. ICPはもともと三次元点列に対して提案されたが, 二次元 にも適用できる，ICPでは，まず，二つのスキャン間で最も近 い点同士を対応づけ，次に，対応つけた各点間の二乗誤差の和 が最小となる相対姿勢を求める。この二つの処理を交互に繰り 返して, 画スキャンが合致する点の対応と相対姿勢を求めてい く.このほか, 相対姿勢の計算において回転の探索と並進の探 索を別々に行う IDC [12] や，スキャン点列をガウス核関数を用 いて濃淡画像に变換し，その輝度勾配からマッチング評価関数 を構成する NDT [2] など, 多くの方法が提案されている。これ らの方法は，曲線を含む複雑な形状もマッチングできるという 特長があるが, 相対姿勢の初期值を必要とするため, 大域的な マッチングはできない.

LineMatch [6] は，入力スキャンから抽出した直線分とマッ プの直線分とを対応づけて大域マッチングを行う。この方法で は, マップはあらかじめ直線分で構成しておき，また，入力ス キャンの直線分はロボットに比べて十分に長いものしか用いな い。このため, 直線分で構成される環境にしか適用できない. APR [17] は，スキャンからコーナ点やステップエッジ点などの 顕著な特徵点を抽出し，それら特徵点をノードとした完全グラ
フのマッチングにより, 特徽点のマッチングを行う。そして, 各 特徵点のマッチング結果を集計してスキャン間の大域マッチン グを行う。この方法は, 少数の顕著な特徴点を用いるため, 特 徵点が少ない環境に適用しにくく，また，ノイズやオクルージョ ンなどによる特徴点の誤検出や欠落に弱い.

\section{2 不変特徵量に基づくマッチング}

コンピュータビジョンの分野では, 不変量に基づく画像マッ チングが研究されている。本稿の提案方式は, Geometric hashing [9] から着想を得ている. Geometric hashingは, 変換の種 類に応じて $n$ 個の特徵点から基底を作り，他の特徽点をその基 底で座標変換することで不変量を生成して，インデックスとし て利用する。スキャンマッチングの場合はユークリッド変換で あるが, Geometric hashing では, $n=2$ 個の特徽点を用いて ユークリッド変換に対する基底を構成していた。しかし, 実際は 1 個の方向付き点があれば基底を構成できる。レーザスキャンで は点の順序が決まっているので, 各スキャン点に対して方向を計 算しやすい。本稿の提案方式では 1 個の特徵点対応を用いるの で，より効率のよいマッチングが実現できる。また, Geometric Hashing では，エッジのコーナ（曲率の極大点）などの特徽点 の抽出を前提としているが, 本方式は特別な特徵抽出を必要と しないので，ロバスト性が増すという利点がある。

SIFT (Scale Invariant Feature Transform) [11] は，相似変 換に不変な特徵点を用いて画像認識を行う仕組みである. SIFT は特徴点 1 個ずつマッチングを行うので, 基本構造は本稿の提案 方式と似ている. 本方式と SIFT の違いは, 特徵点の取り方と特 徵べクトルの構成である. SIFT は濃淡画像を対象とし, DOG (Difference of Gaussian) オペレータによる極值を特徵点とし て抽出する。そして, 特徵点の近傍領域を $4 \times 4$ 個のブロック に分け，各ブロック内に念ま机る画素の方向ヒストグラムを特 徽ベクトルとして用いる，だが，LRF スキャンのような疎な二 次元点列で十分なヒストグラムを得るには, ブロックサイズを 大きくとる必要があり, そうすると類似した特徵べクトルが多 く生じて, 識別力が低くなる。これに対して, 本方式は, 八フ 変換によって直線成分を圧縮することで, 疎な二次元点列でも 識別力の高い特徵ベクトルを得られやすくしている.

ユークリッド不変特徴量を用いた三次元スキャンマッチング 法として, Spin 画像 [8]がある.この方法では, スキャン点を中 心として，そこでの法線を軸とした円筒座標系におけるスキャ ン曲面上の点の分布を特徽べクトルとする．しかし，これを二 次元スキャンに適用しようとすると, 点の分布が疎になりすぎ るため, やはり識別力の高い特徵べクトルを得るのは難しい.

\section{3. 大域候補抽出}

大域候補抽出では，個々のスキャン点に定義した特徵べクト ル（シグネチャ）を用いて，スキャン間の初期姿勢に依存せず に，スキャン点のマッチングを行う。そして，スキャン点間の 相対姿勢をもとに，スキャン間の相対姿勢を求める.

\section{1 シグネチャによる特徴表現}

マッチング特徵として，スキャン点とそこでの接線方向を用い る.このように接線方向を付加した点を有向点 (directed point) と呼ぶ。ここでの接線は、スキャン点を連結した折れ線を曲線 


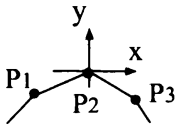

(a) Directed point

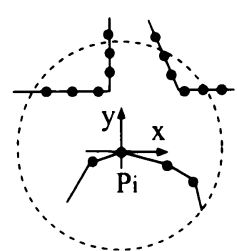

(b) Signature of $P_{i}$
Fig. 1 A directed point and its signatures

とみなした場合の接線である。接線方向は，スキャン内の近傍 にある $n$ 個のスキャン点から計算する. Fig. 1 (a) に, $n=3$ の場合を示す。いま注目しているスキャン点を $P_{2}$ とすると, $P_{1}$ と $P_{2}$, および， $P_{2}$ と $P_{3}$ をそれぞれ結んだ線分の方向の平均 を， $P_{2}$ の接線方向とする，そして， $P_{2}$ を原点とし，この接線 を $x$ 軸として,$P_{2}$ のローカル座標系を定義する.

LRF ではスキャン点の順序が得られるため, 用いるべき $n$ 個 のスキャン点は，その順序に沿って容易に得られる。ただし，ス キャン点が近すぎると接線方向が不安定になるので，単純に隣

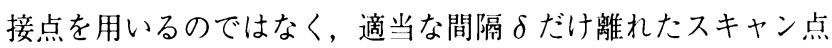
を用いる．現状では， $\delta=100[\mathrm{~mm}]$ 程度としている。

有向点 $P_{i}$ を表すための特徵量として, その周囲 $D$ 内にある 他の有向点 $P_{j}$ の分布パターンを用いる (Fig. 1 (b) 参照)。こ れを $P_{i}$ のシグネチャと呼ぶ. シグネチャを構成する際，各 $P_{j}$ を絶対座標系から $P_{i}$ のローカル座標系に変換する。こうして 変換した有向点からなるシグネチャは， $P_{i}$ の並進回転に対して 不変になる。そこで，シグネチャが一致するかどうかを調べれ ば，入力スキャンと参照スキャンの相対姿勢を問わずに，再者 を構成する有向点の照合ができる，範囲 $D$ は，現状では， 1 個 のスキャン全域としている.

シグネチャ比較の効率化のために，シグネチャを压縮する。 有向点は直線の性質をもつので, これをハフ変換して, 八フ空 間に点として投票する。すると，八フ空間 $(\rho, \theta)$ 上に投票パ ターンが生成される。この投票パターン画像をそのまま使う とデー夕量が多くなるので, 投票パターンの中で投票数の多 いハフ空間点を上位から $N$ 個取り出す。この $N$ 個の点をあ らためてシグネチャと呼ぶ。具体的には， $P_{i}$ のシグネチャを $G_{i}=\left\{g_{i j}=\left(q_{i j}, w_{i j}\right) \mid 1 \leq j \leq N\right\}$ と定義する. $q_{i j}$ はハフ空 間点 $\left(\rho_{i j}, \theta_{i j}\right), w_{i j}$ はその点の投票数である. 実装では, $N$ を 与えるのではなく, $w_{i j}$ が極大となるか所定の閾值 $t h_{1}$ を超え た点を採用している，スキャン形状に依存するが，Nの值は屋 内では $2 \sim 20$ 程度になる。 $t h_{1}$ は 2 5 程度に設定している。

以上の操作により, データ量が大幅に減るとともに, シグネ チャを有向点のインデックスとして用いることが可能になる。 八 フ変換の導入は, 人工環境のように直線の多い形状に特に有利 である. 曲線は, 有向点が離散的であることや八フ空間の離散 化により，実質的に折れ線で近似した形でマッチングされる。こ の場合， 6.2 節で述べるようにシグネチヤは分散するが，その分 布は比較的安定している.

\section{2 インデックステーブル}

スキャン間のマッチングは，次節で述べるように，二つのス キャンの各有向点がマッチングするかどうかで判定する。しか

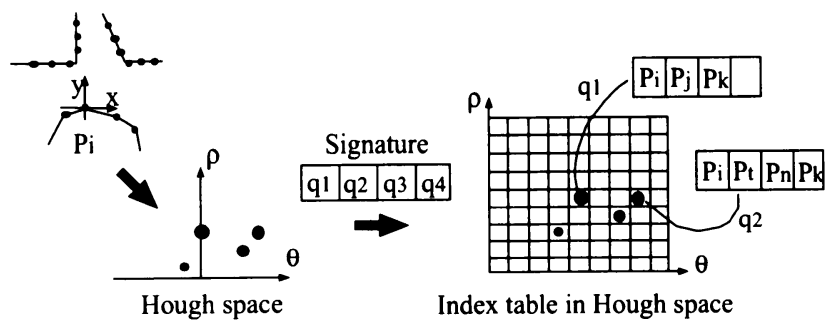

Fig. 2 An index table of directed points

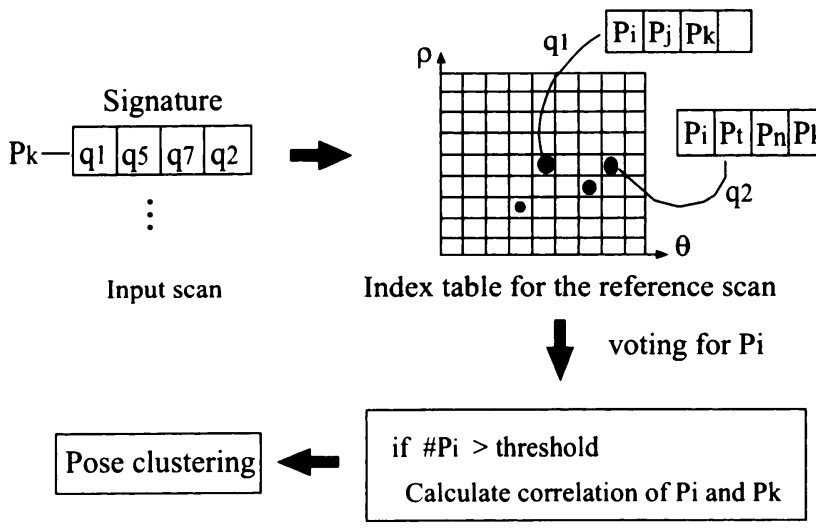

Fig. 3 Matching procedure

し，これを有向点の全組み合わせで調べると処理時間がかかる. そこで，インデックステーブルを用いて効率化を図る.

有向点のインデックステーブルは，以下のように構成する (Fig. 2 参照)。まず，八フ空間を二次元のグリッドに区分し， インデックステーブルとする。 そして，参照スキャンの各有向 点をインデックステーブルに登録する，具体的には，有向点 $P_{i}$ のシグネチャ $G_{i}$ がハフ空間点 $q_{i j}$ をつとき，この点に対応す るインデックステーブルのエントリに $P_{i}$ 自身を登録する。マッ チングの際には, 入力スキャンの有向点 $P_{k}$ のシグネチャを構 成するハフ空間点 $q_{k j}$ のエントリに登録された有向点たけを比 較対象にする (Fig. 3 参照)。このため, $P_{i}, P_{k}$ の全組み合わ せを調べる必要がなく, 効率がよい.

\section{3 有向点のマッチング}

入カスキャンと参照スキャンのマッチングは, 各有向点のマッ チングに基ついて行う，有向点のマッチングは，シグネチャの 一致度を計算して行う。手順を以下に示す。

(1) インデックスの参照

入力スキャンの有向点 $P_{k}$ について，そのシグネチャを構 成する各ハフ空間点 $q_{k m}$ のエントリに登録されている有向 点をインデックステーブルから取り出す．そして， $q_{k m}$ の エントリに有向点 $P_{i}$ が含まれていれば， $P_{i}$ のカウンタを 一つ増やす。これを $P_{k}$ のシグネチャ内の全ハフ空間点に 対して繰り返し, カウンタが所定の閾值 $t h_{2}$ を超えた有向 点を残す. 残った有向点の集合を $\left\{P_{i}\right\}$ とする. 現状では, $t h_{2}$ は $2 \sim 3$ 程度である.

(2) シグネチャの一致度計算

$P_{i}$ と $P_{k}$ のシグネチヤの一致度を式（1）に基づいて計算 し，その值が所定の閾值以上なら，両者はマッチしたとみ 
なす。現状では，一致度の閾値は，0.3〜0.5 程度である。

$$
\begin{aligned}
C_{i k} & =\frac{\sum_{n, m} f\left(g_{i n}, g_{k m}\right)}{\sqrt{\sum_{n} w_{i n}^{2} \sum_{m} w_{k m}^{2}}} \\
f\left(g_{i n}, g_{k m}\right) & = \begin{cases}w_{i n} w_{k m} & \text { if } q_{i n}=q_{k m} \\
0 & \text { otherwise }\end{cases}
\end{aligned}
$$

\section{4 姿勢クラスタリング}

マッチした有向点ペアを用いて，姿勢クラスタリングにより スキャン間の相対姿勢を求める。姿勢クラスタリングは，一般 には，データとモデルの間で対応づけた特徵ぺアの集合から両 者間の相対姿勢を求める技術であり，物体認識などで広く用い られる [5] [9] [11] [14]. いま, Fig. 4 に示すように，ロボットが 姿勢 $R_{1}$ から $R_{2}$ に移動したとする． $R_{1}$ で得たスキャンを参照 スキャン， $R_{2}$ で得たスキャンを入力スキャンとする。両スキャ ンが一致したと仮定して，その中の有向点 $P$ を考える。姿勢 $R_{1}$ のローカル座標系での $P$ の值を $P_{1}=\left(x_{1}, y_{1}, \theta_{1}\right)$, 姿勢 $R_{2}$ のローカル座標系での $P$ の值を $P_{2}=\left(x_{2}, y_{2}, \theta_{2}\right)$ とする. $\theta_{1}$, $\theta_{2}$ は有向点の接線方向である. $P_{1}, P_{2}$ は, そ玌ぞれ, 参照ス キャン, 入力スキャン内での有向点の值に相当する。ロボット の移動量を $q=(x, y, \theta)$ とすると, 次式が成り立つ.

$$
\begin{aligned}
& \theta=\theta_{1}-\theta_{2} \\
& x=x_{1}-\left(x_{2} \cos \theta-y_{2} \sin \theta\right) \\
& y=y_{1}-\left(y_{2} \sin \theta+y_{2} \cos \theta\right)
\end{aligned}
$$

もし，参照スキャンと入力スキャンが完全に一致するなら，入 カスキャン内のすべての有向点について上式が成り立つはずで ある。したがって，対応の正しい各有向点ペアについて上式を 解けば，理想的には，すべて同じ $q$ が得られる，実際には，点 の誤対応や䛊差などが原因で，完全に同じ $q$ が得られることは ない。 そこで，各有向点 $P$ について上式を解いて得られた $q$ に ついてクラスタリングを行って，解候補を求める。シグネチャ を用いた有向点マッチングによって有向点ペアが絞り込まれて いるので，多くの場合，明確なクラスタが形成される.

姿勢クラスタリングにはいくつかの方法があるが，本研究の 実装では，回転 $\theta$ を投票により求め, 並進 $x, y$ をクラスリ ングで求める。まず，各 $q$ の $\theta$ を角度ヒストグラムに投票して， 投票值が所定の闇值を超え，かつ，極大となる角度を候補とし て採用する。実装では，角度ヒストグラムの刻みは 1 度にして いる。次に，この候補角度に合う $q$ だけ取り出し，その $x, y$ に関してボトムアップ・クラスタリングを行う。そして, 要素 数が多いクラスタの重心を, 解候補として採用する。実装では, その要素数の閥値は最大クラスタの要素数の $0.2 \sim 0.4$ 倍程度と している.

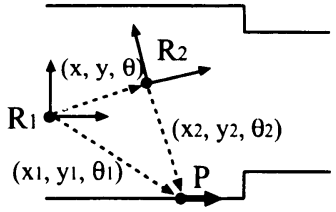

Fig. 4 Relationship between scans and robot pose
回転成分を投票で求める理由は，角度範囲が 0 ３59 度に限 定されるので，ヒストグラムを構成しやすいためである。一方， 並進成分は，その範囲を規定するのが難しいため，ヒストグラ ムを必要としないクラスタリングを用いている。

\section{4. 詳細マッチング}

大域候補抽出の姿勢クラスタリングでは近似解しか得られな いので，誤差を最小化するように微調整が必要である。また， 大域候補抽出では一般に複数の候補が得られるが，マッチング 結果を大域自己位置推定で利用するには，候補を一つに絞らず， 有力な候補を複数個残すようにした方がよい。そこで，大域候 補抽出で得られた各候補のうち有力なものを保持しつつ，それ ぞれの誤差が最小になるように詳細マッチングを行う。

\section{1 誤差の最小化}

大域候補抽出で得た姿勢候補に対して，入力スキャンと参照 スキャンの間で対応点の位置の二乗誤差が最小になるように最 適化を行う。基本的には，ICP と同様に，スキャン点の対応つ けと最小二乗計算を交互に行う。ただし，最小二乗計算を遺伝的 アルゴリズムを用いて計算する点が異なる．以下に手順を示す．

(1) スキャン点の対応づけ

入力スキャンの各スキャン点に最も近いスキャン点を参照ス キャンから求める。このために，ICP ではスキャン点間の距離 を用いるが，スキャン点は離散化されているため，二つのスキャ ン間でスキャン点の位置が完全に一致することは少なく，誤差 が大きめに出る可能性がある。これに対処するために，隣接す る参照スキャン点が張る線分と入力スキャン点との距離を用い る方法もあるが，計算コストがやや高い，そこで，本方式では参 照スキャン点の接線と入力スキャン点との距離を用いる。すな わち, 入力スキャン点の近傍にある参照スキャン点のうち, 参照 スキャン点の接線と入力スキャン点との距離が最も小さいもの を対応点として採用する. 参照スキャン点の接線は, 有向点算出 の際に得られているのでその取得に余分なコストはかからない． さらに，接線の方向誤差を，点の対応づけにおけるフィルタと して用いる．すなわち，接線の方向䛊差が所定の閾值 $(30[\mathrm{deg}]$ 程度）より大きい場合は，対応点とみなさない。

(2) 解候補の計算

現在の姿勢候補で得ら机たスキャン点対応に対して, 次式に よりスキャン間の二乗誤差を評価する.

$$
D(\mathbf{q})=\frac{1}{N} \sum_{i}^{N} d\left(P_{i}, \mathbf{q}\right)^{2}
$$

$N$ は入力スキャン点数である. $d\left(P_{i}, \mathbf{q}\right)$ は，スキャン間の相対 姿勢が $\mathbf{q}$ のとき, 入力スキャン点 $P_{i}$ から対応する参照スキャ ン点の接線までの距離である。

ICP では, $D(\mathbf{q})$ を最小にする $\mathbf{q}$ を陽に解くが，その場合，点 の䛊対応の扱いが難しい，䛊対応点を含めて $D(\mathbf{q})$ を作って最 小二乗解を求めると，䛊対忍による誤差が全体に分散してマッ チングは微妙にずれる。これは，オクルージョンなどにより二 つのスキャンの形状が異なる場合に顕著になる。そこで，初期 段階では多少の䛊対応を許容しつつ，次第に誤対応を取り除い て最終的にぴったり合致するよう，誤対応判定の閯值をうまく 
制御する必要がある。しかし，これは一般に難しい。䛊対応と 判定された点は $D(\mathbf{q})$ から除かれるので, $D(\mathbf{q})$ 自体が変化し, 全体の挙動が複雑になり，極值に陥りやすくなるためと考えら れる.

これに対処するため，本方式では， $D(\mathbf{q})$ の最小化を遺伝的 アルゴリズムによる探索で行う。まず，点の䛊対応は次のよう に扱う. 式 $(6)$ で, $d\left(P_{i}, \mathbf{q}\right)$ が閾值 $d_{0}$ より大きくなると, そ の $P_{i}$ を䛊対応点とみなして $d\left(P_{i}, \mathbf{q}\right)=d_{0}$ と一定にする.こ うすると, 䛊対応の有無による $D(\mathbf{q})$ の変化は小さくなり, 安 定した結果が得られやすい. $D(\mathbf{q})$ の最小化は勾配法でも行え るが，極值に陥る可能性を減らすために，交叉なしの遺伝的ア ルゴリズムを用いる。この遺伝的アルゴリズムの実装は，パー ティクルフィルタとよく似たものになる，そこで，遺伝的アル ゴリズムで探索点として用いる各個体をパーティクルと呼ぶこ とにする。

計算には， $M$ 個のパーティクルを用いる。各パーティクルは スキャン間の相対姿勢と重みをもつ。相対姿勢の初期值には, 大域候補抽出で得られた各候補を割り当てる.そして, 各パー ティクルごとに，その相対姿勢をランダムに微小量だけ変動さ せ，そのときの相対姿勢 $\mathbf{q}$ に対する二乗誤差 $D(\mathbf{q})$ を計算して, 重み $\exp \left(-D(\mathbf{q}) / \sigma_{0}\right)$ をパーティクルに与える。 $\sigma_{0}$ は重み分布 の鋭さを決める定数である。そして，この重みに比例した確率 で，パーティクルをリサンプルする。このリサンプリングによ り，大きな重みをもつパーティクルがより多くの子棌を残すこ とになる。これを繰り返すと, 個数 $M$ が一定なので, $D(\mathbf{q})$ が 大きいパーティクルは死滅し, 小さいパーティクルは生き残る. これにより，二乗䛊差が最小となる解候補を近似的に求める.

\section{2 複数候補の対処}

大域候補抽出で得られた各候補をそのまま前節の遺伝的アル ゴリズムのパーティクルに割り当てると, 最良スコアのものが 一人勝ちすることが多く, 有力な解候補が複数残らなくなる.こ れは，次の理由による。最適值に近い解候補を速く求めるには, パーティクルの重み $\exp \left(-D(\mathbf{q}) / \sigma_{0}\right)$ の分布が急峻なことが望 ましい，そうすれば，二乗䛊差 $D(\mathbf{q})$ が小さいほど重みが急速 に大きくなり，大量の子孫を残せるため，探索が効率的に進む. ところが，このようにすると， $D(\mathbf{q})$ の最小值付近の重みが他 の極小值付近の重みよりずっと大きくなり, 最小值にパーティ クルが集中して, 他の極小值にパーティクルが残らなくなる.

複数の有力候補を残すためには，このような現象を防ぐ必要 がある。そこで，パーティクルをクラスタに分類し，各クラス タごとに遺伝的アルゴリズムを適用する。ここでのクラスタは， $D(\mathbf{q})$ の極小点の近傍にあるパーティクル集合である. クラス 夕自身も重みをもち, クラス夕がもつパーティクル数は, その クラスタの重みに比例して決める。これにより, 有力なクラス 夕には多くのパーティクルが配分される。そして，クラス多内 のパーティクルの重み分布は急峻にし, クラスタの重み分布は 緩やかに変化するようにする。これにより，各クラス夕を維持 しながら, クラス夕内での最適解は迅速に求めることができる.

この手順を以下に示す. (2)～(5) は所定回数だけ繰り返す. $\mathbf{q}_{j}$ の初期值は, 大域候補抽出で得られた各候補である。処理開 始時のクラス夕は，各候補を表すパーティクル 1 個からなるが,
クラスタの併合を繰り返して，大きなクラスタに収束していく.

(1) 初期化

大域候補抽出で得られた各候補をパーティクルに割り当て る. 各パーティクル $j$ の相対姿勢 $\mathbf{q}_{j}$ において, 4.1 節で述 ベたスキャン点の対応づけを行い， $D\left(\mathbf{q}_{j}\right)$ を計算する. 初 期クラス夕は各パーティクル 1 個ずつで構成する.

(2) クラスタの重み計算

クラスタ $i$ 内のパーティクルの $D\left(\mathbf{q}_{j}\right)$ の最小値を $D_{i}$ とす ると, クラスタ $i$ の重み $C_{i}$ を次式で設定する.

$$
C_{i}=\alpha \cdot \exp \left(-D_{i} / \sigma_{c}\right)
$$

$\sigma_{c}$ はクラス夕間の重み分布を決める定数である。 $\alpha$ は, 全 クラスタの重みの和を 1 にするための正規化定数である.

(3) クラスタ内パーティクル数の計算

クラスタのパーティクル数 $N_{i}$ を次のように決める. round は四捨五入関数である.Mは全パーティクル数である. $N_{i}$ が0になったクラスタは除去する。

$$
N_{i}=\operatorname{round}\left(M C_{i}\right)
$$

(4) クラスタごとの最適化

各クラスタ内で以下の処理を繰り返す。

(a) パーティクルの拡散

各パーティクルの $\mathbf{q}_{j}$ をランダムに微小量だけ変動させる.

(b) パーティクルの重み計算

$\mathbf{q}_{j}$ に対してスキャン点の対応づけを行い, $D\left(\mathbf{q}_{j}\right)$ を計算 して，重み $w_{j}$ を次のように設定する.

$$
w_{j}=\exp \left(-D\left(\mathbf{q}_{j}\right) / \sigma_{0}\right)
$$

(c) リサンプリング

$w_{j}$ に比例した確率で，パーティクルをリサンプルする.

(5) クラスタの併合

中心の距離が近いクラスタは併合する.クラスタ中心は, ク ラスタ内の最良パーティクルとする.

この方法では, クラスタ間の重み分布 $\sigma_{c}$ を大きく, クラスタ 内の重み分布 $\sigma_{0}$ を小さく設定すれば, 弱いクラス夕の重みを 急激に減少させずに, 各クラスタ内では迅速に最適值に収束さ せることができる。

なお，極小值に陥るのを避けるためには，遺伝的アルゴリズ ムを用いなくても, 候補点の近傍に複数の初期值を配置して, そ れぞれに対して勾配法で式 $D(\mathbf{q})$ を最小化する方法も考えられ る。しかし，その場合，大域候補抽出で得られた全候補のそれ ぞれについて勾配法を実行するため, 全候補数と初期值数の積 に比例した計算量がかかる。一方ここで述べた遺伝的アルゴ リズム手法では, 最初に全候補を 1 回評価した後は, 評価值の 良いものだけに絞り込まれるため, 全体としては, パーティク ル数 (固定值) に比例した計算量となる. 以上のことから, 大域 候補抽出で得られた候補数が大きい場合, 本手法が有利になる。

\section{5. マップ構築と大域自己位置推定}

提案方式をマップ構築および大域自己位置推定に応用する方 法を述べる。 


\section{1 マップ構築}

LRF のスキャンを用いてマップ構築を行うには，ロボットが 走行しながら収集したスキャンを, 各計測地点でのロボット姿 勢に従ってマップ座標系に配置していけばよい。一般に，ロボッ ト姿勢は，オドメトリなどの内界センサによって取得できるが, オドメトリは累積誤差があるため, オドメトリだけから推定し たロボット姿勢を用いて生成されたマップは歪む。一方，ロボッ トの速度に対して十分短い間隔でスキャンを計測すれば，時間 的に隣接するスキャンは重なり合う部分が大きくなる。そこで, それまで生成したマップと入力スキャンの間でスキャンマッチ ングを行い，スキャンをマップに追加していけば，マップを構築 することができる。このとき，オドメトリは必ずしも必要ない．

本稿で提案したスキャンマッチング方式をマップ全域に用い ると, 一般に解が複数得られるが, マップ構築では解を 1 個に 絞る必要がある。そこで, マップ全域で大域マッチングを行う のではなく，局所領域に限定して行う。スキャンマッチングで 得られるロボットの位置の移動量を $\Delta d$, 万向変化を $\Delta \theta$ とす ると,マッチング範囲を次の領域に限定する.

$$
(|\Delta d| \leq R) \wedge(|\Delta \theta| \leq \Theta)
$$

範囲 $R$ と $\Theta$ は, ロボットの走行速度とスキャンの測定時間間隔に 応じて決めればよい. 例えば，ロボットの走行速度が $200[\mathrm{~mm} / \mathrm{s}]$, 最大回転角速度が $30[\mathrm{deg} / \mathrm{s}]$, スキャン測定間隔が $1[\mathrm{~s}]$ であれ ば, $R=200[\mathrm{~mm}], \Theta=30[\mathrm{deg}]$ とすればよい. 実際には，ス リップなどに備えて十分なマージンを加えるのがよい. 局所領 域が小さければ，単純形状による退化が起こらない限り，マッ チングはほとんど一意に決まると期待できる。したがって，そ の範囲内では, マッチングスコアが最良の解を正解と見なして マップを構築する。この方法は, 無䭾な候補の生成を防ぐとと もに，マップ全域でマッチングを行うよりも処理時間がはるか に小さくて済むという利点もある。なお，オドメトリを用いれ ば，局所領域をさらに小さく限定でき，精度と効率が向上する.

以下に,マップ構築の手順をまとめる.

(1) 初期化

時刻 $t=0$ では, ロボット姿勢 $r_{0}$ をマップ座標の原点にお くそそして，入力スキャンをそのままマップ $m_{0}$ にする.

（2）ロボット姿勢の計算

時刻 $t$ で得た入力スキャン $s_{t}$ とマップ $m_{t-1}$ でスキャン マッチングを行い, その最良解を $q_{t}$ とする。 マップを参照 スキャンとす枕ば，3.4 節の議論により，qtがそのままマッ プ座標系でのロボット姿勢 $r_{t}$ となる.

(3) マップ構築

$r_{t}$ に基づいて $s_{t}$ を座標変換してマップ $m_{t-1}$ に統合し, $m_{t}$ を得る。この際，その後のマッチングに用いるために，新 スキャンに含まれる有向点をインデックステーブルに追加 する，有向点のシグネチャはそのまま用いる。なお，デー 夕量が増えすぎるのを防ぐため, 近くに既存の有向点が存 在する場合はマップに統合しない.

このアルゴリズムは確率を考慮していないので, 生成された マップでは，ロボット姿勢やスキャン位置の確定值しか得られ ない. スキャンマッチングで最小二乗推定を行っているので, 誤
差をガウス分布と仮定すれば，ほぼ最尤值に近いマップが得ら れるが，その不確実性の度合い(誤差分散) は得られない。不 確実性も求めるには, スキャンマッチングの結果に確率分布を 導入し, SLAM の確率的定式化に基づいてロボット姿勢とマッ プの確率分布を求める必要がある。この詳細は, 本稿の範囲を 超えるので，別の機会に報告する.

\section{2 大域自己位置推定}

大域自己位置推定では, マップを所与として，ロボットの初 期姿勢を与えずに，マップ全域で大域スキャンマッチングを行 えばよい. 3.4 節の議論により, 大域スキャンマッチングの解が マップ座標系でのロボット姿勢の候補となる。

環境内に類似した領域があれば，大域スキャンマッチングでは， ロボット姿勢は複数得られる。本稿では詳細は割愛するが,これ らの複数候補をもとに複数仮説追跡を行って整合のとれた候補に 絞り込むことで, 正しい自己位置を得ることができる [4] [7] [16]. このように大域スキャンマッチングと仮説追跡により, 大域自 己位置推定が実現できる。

大域自己位置推定は, ナビゲーションにもマップ構築にも有 用である.ナビゲーションの最中に, 大きな外乱によって自己 位置を見失っても，大域自己位置推定ができれば，自律的に復 帰することが可能になる。マップ構築においても，走行中に自 己位置を見失うことは起こり得る。この場合, マップ構築を一 時中断し, 本方式を用いて大域自己位置推定を行ってロボット 姿勢の候補が 1 個に絞られた時点で,マップ構築を再開すれば よい. 本方式は, マップ構築と大域自己位置推定の両方に使え るので，このように両者が連携する処理に適している.

大域自己位置推定は, マップ構築でのループ検出やマップ併 合にも有用である。ループ検出では，ロボットが環境を一周し て同じ地点に戻ったことを検出するが，ロボットの走行軌跡か らループの様子が分かるので, 大域マッチングの範囲を限定す ることができる。そのため, 完全な大域マッチングよりも効率 がよい.また,マップ併合では, 別々に作成したマップをつな ぎ合わせて大きなマップを作る際に, 各マップの連結領域を求 めるのに利用できる。

\section{6. 実験}

筑波大学知能ロボット研究室で開発された移動ロボット「山 彦」にSICK 社の LRF である LMS200を搭載して, 筑波大学 の実験室㧍よび廊下にて実験を行った，後出の Fig. 12 (a) にロ ボットを示す. LMS200 は, スキャン範囲を - 90 ～ $90[\mathrm{deg}]$, 角 度分解能を $0.5[\mathrm{deg}]$, 距離範囲を $8[\mathrm{~m}]$ として使用した。

\section{1 スキャンマッチングの基礎実験}

提案方式の動作を確認するために, 基礎実験を行った. Fig. 5

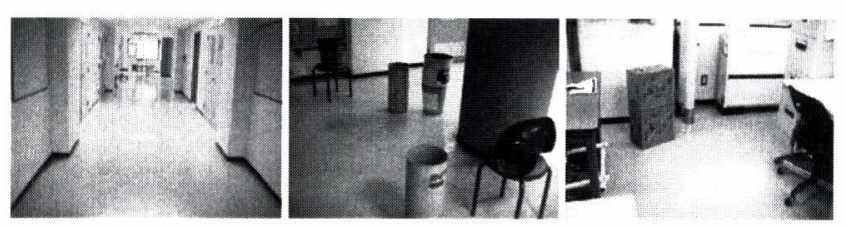

(a) Corridor

(b) Curved objects

(c) Room

Fig. 5 Experimental environments 
に実験環境を示す。ノートPCからロボットを操縦して環境内を $100[\mathrm{~mm} / \mathrm{s}]$ で走行させ, LRF のスキャンを 2 秒おきに取得した. Fig. 5(a)の廊下 (Corridor) では 87 個, Fig. 5(b)の曲線環境 (Curved objects) では 75 個，Fig. 5 (c) の実験室（Room）で は93 個のスキャンを収集した. Fig. 5 (b) は円筒形の物体を並 べて人為的に曲線環境を作った。そこで収集した LRF データ には，背後に直線の壁があるが，形状が曲線のみから構成され るように，2,750[mm] より遠いスキャン点をプログラムによっ て削除することにより, 直線成分となる壁を取り除いた。

これらのスキャンを用いて，マッチング範囲を限定せずに大 域マッチングを行ってマップを構築した。マッチング候補が複 数得られたときは，スコアが最良のものを選択した。この実験 では，すべてのスキャンのマッチングに成功した. Fig. 6 に生 成したマップを示す。

なお, Curved objects は, 従来手法の LineMatch や APR ではマッチングできない例である。 LineMatch は直線環境に適 用が限定される. APRは, 曲線の端点は視点によって变化する ため特徵点として採用しないので, Curved objectsでは特徵点 がほとんどとれない。

\section{2 シグネチャの安定性}

前節での実験結果を用いて, シグネチャの安定性を調べた。 Fig. 7 に, Fig. 6 の有向点 $P_{1}, P_{2}$, および, $P_{3}$ のシグネチャ を示す. Fig. 7 (a) は, Fig. 6 (a)の 87 個のスキャンの中からラ ンダムに選んだスキャン内の一つの有向点 $P_{1}$ (正確には， $P_{1} に$ 最も近い有向点) のシグネチャである. Fig. 7 (b) は, Fig. $6(\mathrm{a})$ のすべてのスキャンにおける $P_{1}$ のシグネチャを平均化したもの である. 同様に, Fig. 7 (c), (d) は, Fig.6 (b)の $P_{2}$ について, スキャン 1 個とスキャン平均のシグネチャである. Fig. 7 (e), (f) は, Fig. 6 (c) の $P_{3}$ について, スキャン 1 個とスキャン平均 のシグネチャである。この図から分かるように，ランダムに選

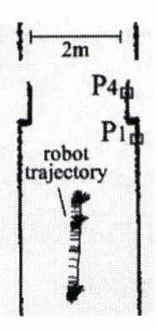

(a) Corridor (87 scans)

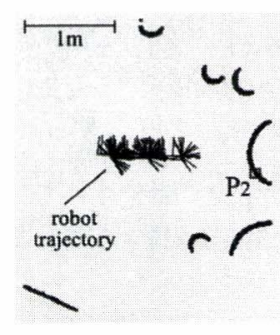

(b) Curved objects (75 scans)

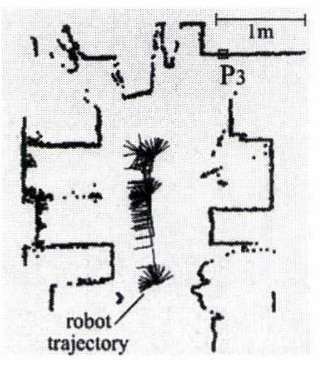

(c) Room (93 scans)
Fig. 6 Generated maps

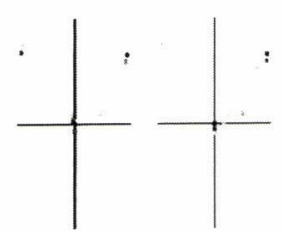

(a) $P_{1}$

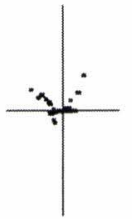

(c) $P_{2}$

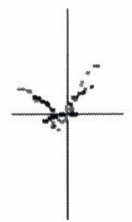

(d) $P_{2}$

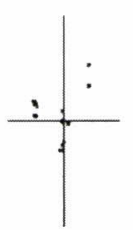

(e) $P_{3}$

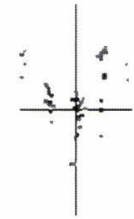

(f) $P_{3}$ (one scan) (all scans) (one scan) (all scans) (one scan) (all scans)

Fig. 7 Examples of signatures
んだスキャンに扔けるシグネチャと, 全体の平均シグネチャは よく似ている。このことは, 有向点のマッチングがシグネチャ で可能であることを定性的に示している.

$P_{i} \quad(i=1$ to 3$)$ のシグネチャに, $n(n=1$ to 4$)$ 個以上 の同じハフ点が含まれるスキャン対の比率をTable 1 に示す. 例えば， $P_{1}$ のシグネチャでは，3,160 個のスキャン対のうちの $57.2 \%$ が，2 個以上の同じハフ点を持っていることを表す。この 3,160 個のスキャン対は実際はすべて $P_{1}$ を含んでおり，理想的 にはすべてのスキャン対で $P_{1}$ がマッチングできるはずである. したがって,この結果は, おおざっぱに言うと, 3.3 節での闇值 $t h_{2}$ を 2 としたとき， $P_{1}$ のマッチング率は $57.2 \%$ であることを 意味する． $P_{1}$ は無作為にとった点であるから, 他の有向点につ いても同様と予想される. 正しくマッチングした有向点のペア は, 姿勢クラスタリングにおいて, 同じ相対姿勢のビンに投票 される．57.2\%の正しい有向点ペアがあれば，姿勢クラスタリ ングに拈いて，十分に大きなクラス夕が生成されると期待され る、実際は，もっと少ない有向点ペアでも十分大きなクラス夕 が生成されるが, 実装においては, 検出もれを防ぐために, 䦨 值 $t h_{2}$ は低めにし $2 \sim 3$ 程度に設定している.

\section{3 シグネチャの識別性}

次に，シグネチャの識別性を調べた．前節と同じ対象におい て，あるスキャンの有向点のシグネチャと別のスキャンの全有向 点のシグネチャとのマッチングスコアを式 (1) により計算した. Fig. 8 にその様子を示す. 横軸は有向点番号, 縦軸はマッチング スコアである. 有向点は, Fig. $7 の P_{1} \sim P_{4}$ を用いた. Corridor 上の $P_{1}$ については，ほとんど同じシグネチャをもつ有向点が 他にも多数存在する。これは, 廊下の主要構成要素が 2 本の平 行線であるためである。一方， $P_{4}$ は廊下の突起部（柱）上の 点であり，壁上の点とは異なるシグネチャをもつため, 識別性

Table 1 Signature matching rate

\begin{tabular}{|c|c|c|c|c|r|}
\hline & 1 & 2 & 3 & 4 & total pairs \\
\hline$P_{1}$ & $76.2 \%$ & $57.2 \%$ & $40.3 \%$ & $22.8 \%$ & 3160 \\
\hline$P_{2}$ & $78.9 \%$ & $53.1 \%$ & $32.5 \%$ & $20.0 \%$ & 2701 \\
\hline$P_{3}$ & $64.7 \%$ & $46.4 \%$ & $33.9 \%$ & $23.9 \%$ & 3916 \\
\hline
\end{tabular}

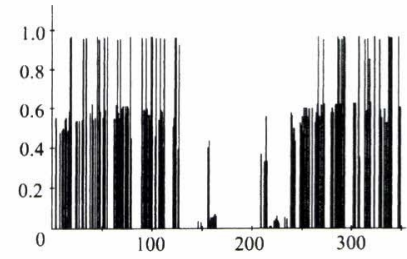

(a) $P_{1}$ on a corridor scan

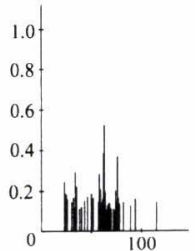

(c) $P_{2}$ on a curved objects scan

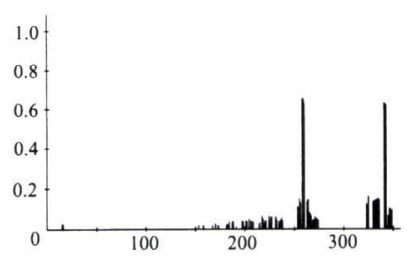

(b) $P_{4}$ on a corridor scan

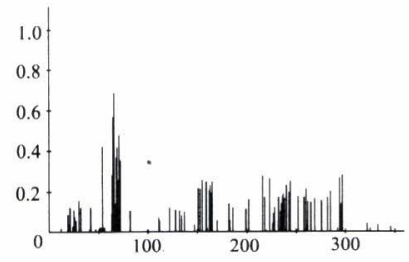

(d) $P_{3}$ on a room scan
Fig. 8 Matching scores of an input directed point with all the reference directed points 
が高くなっている. $P_{2}$ は, Curved objects 上の点であり，シ グネチャはFig. 7のように広がりをもつため, マッチングスコ アの高い有向点が比較的多く得られる。 $P_{3}$ は Room 上の点で あり，環境形状が複雑なので識別性が高いことが分かる。なお， Curved objects のスキャンは，背後の壁を人為的に取り除いて いるため有向点数は 140 点となり, Corridor や Roomよりも 有向点数が少ないことに注意されたい.

類似したシグネチャをもつ有向点の比率を Table 2 に示す. これは， $P_{1} \sim P_{4}$ に対して，Fig.8の各点のマッチングスコアが 閾值 $t h$ 以上となる有向点の個数比率を表している。この表から 分かるように，閾值を低めに設定しても，P 1 を除けば，シグネ チャが類似した有向点を数\%にまで絞り込むことができる。こ のようにして絞り込んだ有向点ペアを用いて姿勢クラスタリン グを行えば, 明確なクラスタが得られやすくなり, 高い確率で マッチングが成功すると期待される。

\section{4 マップ構築}

(1) 廊下

筑波大学校舎の廊下でマップ構築の実験を行った. Fig. 9 に廊 下の様子を示す、ロボットをりモコンで操縦して全長約 $400[\mathrm{~m}]$ の経路を走行させ，スキャンデー夕を収集した彴，提案方式に よりオフラインでマップを構築した。ロボットの速度は200 $300[\mathrm{~mm} / \mathrm{s}]$, スキャンは 2 秒ごとに取得した. 大域マッチング によるマップの併合実験も行うために，スキャンデータは，全 経路を重複する四つの部分に分け，それぞれを別個に収集した。 経路の分割箇所は走行中に無作為に決めた。そのうちの一箇所 はバッテリ交換を行うために中断したものであった。中断した 際は, 中断位置より約 $10[\mathrm{~m}]$ 㞍った地点から走行を再開させて, 経路に重複する部分を作った。

収集したスキャンをオドメトリ情報だけに基づいて配置して生 成したマップを Fig. 10 に示す。山彦のオドメトリは精度がよい が，長距離を走ると䛊差が累積し，長方形をなす長さ約 $300[\mathrm{~m}]$ のループでは, 最終的に約 $20[\mathrm{~m}]$ の誤差が生じ, 形が歪んで いる.

提案方式のスキャンマッチングだけで生成したマップを Fig. 11 に示す。オドメトリ情報は用いていない. 5.1 節で述 ベたマッチング範囲は, 式 $(7)$ で $R=1[\mathrm{~m}], \Theta=90[\mathrm{deg}]$ とした. Fig. 11 に示すように，本方式の䛊差は小さい，長さ $300[\mathrm{~m}]$ のループ部分の䛊差は $1[\mathrm{~m}]$ 程度におさまっている. 全 長 $400[\mathrm{~m}]$ の経路全体でも, 最終的な䛊差は 1〜2[m] である.

Table 2 Distinguishability of directed point

\begin{tabular}{|c|c|c|c|c|}
\hline & $P_{1}$ & $P_{2}$ & $P_{3}$ & $P_{4}$ \\
\hline th $=0.2$ & $36.0 \%$ & $6.3 \%$ & $6.6 \%$ & $1.7 \%$ \\
\hline th $=0.3$ & $36.0 \%$ & $2.1 \%$ & $1.9 \%$ & $1.7 \%$ \\
\hline
\end{tabular}
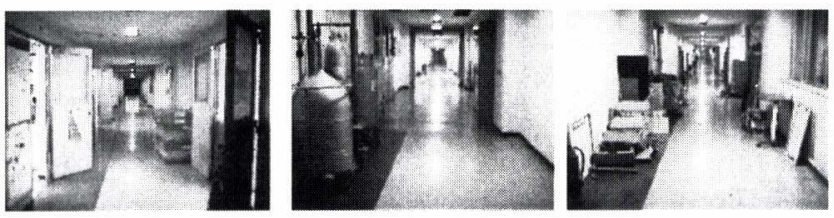

Fig. 9 Experimental environment (corridors)
オドメトリによるマップよりも歪みが小さい理由として，オド メトリ誤差はバイアスをもちやすいのに対し，スキャンマッチ ングの䛊差は偏りなくばらつくことが考えられる。また，スキャ ンマッチングの方がオドメトリに比べて，特に回転時の角度の 誤差が小さいことも要因の一つと考えられる。なおループを 構成する各スキャンの位置を微調整して，最初と最後のスキャ ンが一致するようにループを閉じる処理は、マップ構築におい て重要な問題であるがここでは行っていない.

また，四つに分けたスキャンデー夕をつなぎ合わせるため， マップ併合を 3 回行った。このとき，次のスキャン集合に属する 最初のスキャンを用いて，それまでに作成したマップ全域とマッ チングさせた。スキャン集合の 2 番目のスキャンからはマッチ ング範囲を限定して，それまでと同じようにマップ構築を行っ た. 大域マッチングを 3 回行ったことになるが, いずれも複数 候補の中からスコア最良のものを選ぶだけで正しいマッチング ができた。廊下は形状が単純なため多義性が大きいが，この例 では，つなぎ目付近に置かれた物品によって形状に一意性があっ たため，大域マッチングに成功したと考えられる。なお，才ド メトリ值に基づくマップ構築でも，つなぎ目の部分だけは大域 スキャンマッチングを施している.マップのつなぎ目を Fig. 10， Fig. 11 の点線の円で示す.

マッチングからマップ生成までの処理時間は, Pentium4 $3.0 \mathrm{GHz}$ で，1 スキャン当たり 100〜300[ms]である。ただし， マップ併合のようにマップ全体で大域マッチングを行う場合は, 処理時間はスキャン形状に大きく依存する。スキャン形状が複 雑であれば, $1[\mathrm{~s}]$ 以内で済む。だが, 平行線に近い単純な形状 はマップ全体に多数存在するため，マッチングに3〜10 [s] 程度 の時間がかかることがある。この高速化は今後の課題である。

スキャン数は全部で 838 個であるが，マッチングに失敗した のは 2 - 個である。こ机はパラメー夕の設定值に依存する。あ

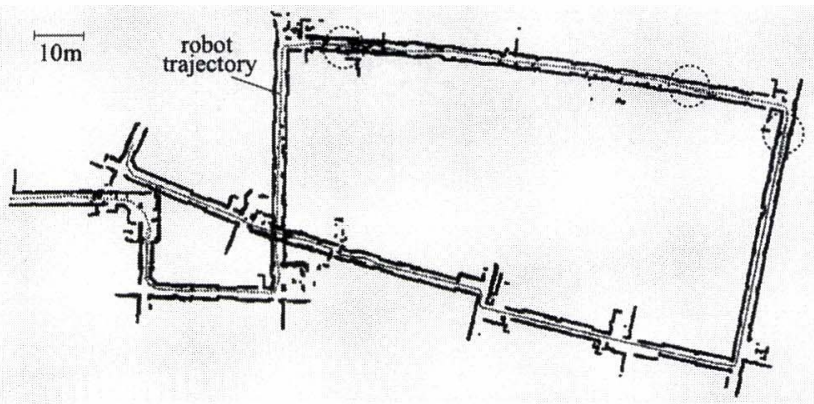

Fig. 10 Corridor map generated from odometry readings

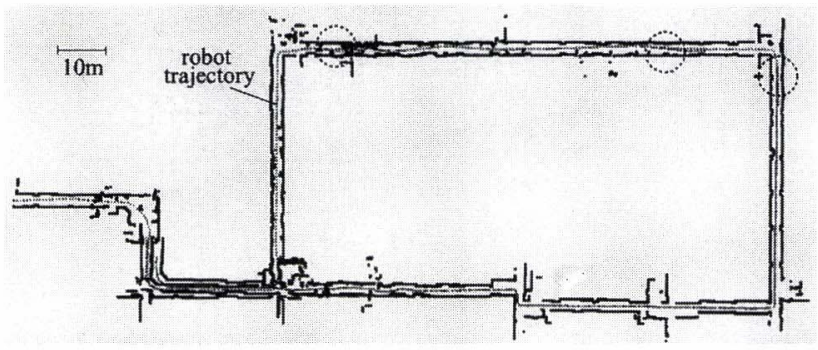

Fig. 11 Corridor map generated by scan matching 
らゆる環境で適切なパラメー夕值を設定するのは困難であるが, この程度の失敗率であれば，オドメトリを併用することで十分 なロバスト性が得られると考えられる。後述のように，一般に， 大域マッチングでは，単純形状のスキャンは多数の候補が生成 され，スコア最良のものが正しいとは限らない.上記のように 高いマッチング率が実現したのは，5.1 節で述べたようにマッチ ング範囲を狭めているからである。

(2) 実験室

形状が複雑な環境として，実験室のマップ構築の実験を行つ た.Fig. 12 (a) にロボットを，Fig. 12 (b) に実験室の様子を示 す。ロボットの走行速度は $100[\mathrm{~mm} / \mathrm{s}]$ で，スキャンは $2[\mathrm{~s}]$ 間隔 で取得した。Fig. 13 に生成したマップを示す.Fig. 13 (a)は, オドメトリ情報だけを用いてスキャンを配置して構築したマッ プである。このマップは 1 周した時点で $300[\mathrm{~mm}]$ 程度の䛊差 がある。Fig. 13 (b) は，オドメトリ情報在用いずに，提案方式 のスキャンマッチングだけで生成したマップである。マッチン グ範囲は, 式（7）において， $R=1[\mathrm{~m}], \Theta=60[\mathrm{deg}]$ とした。 このマップはFig. $13(\mathrm{a}) に$ に比べると形状にぶれが少なく, 誤差 は $50[\mathrm{~mm}]$ 以内である. スキャン数は 168 個であり，すべての マッチングに成功した。

(3) 詳細マッチングの評価

4 章で述べた方式を評価するために，次の三つの場合を比較 した。いずれもオドメトリ情報は用いていない.

・ケース 1（大域マッチングのみ）

大域マッチングを行った後，その候補を式（6）で評価して スコア最良の候補を採用した。式（6）の最適化は行ってい ない。

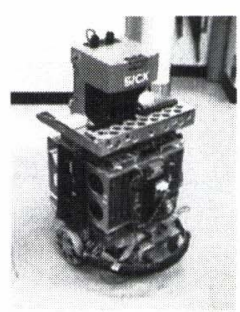

(a) Robot

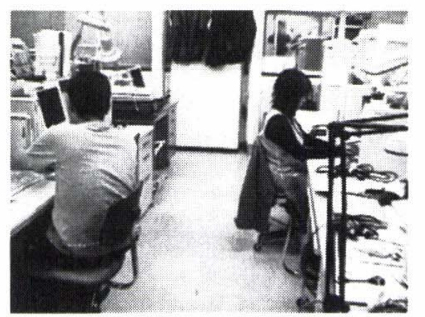

(b) Room
Fig. 12 Experimental environment (room)

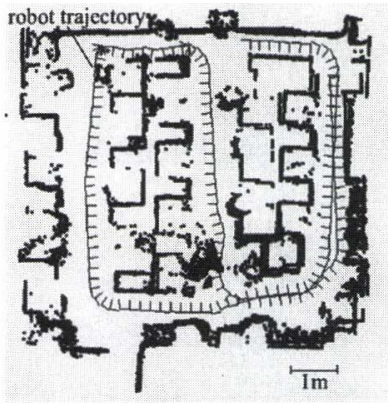

(a) Map from Odometry data

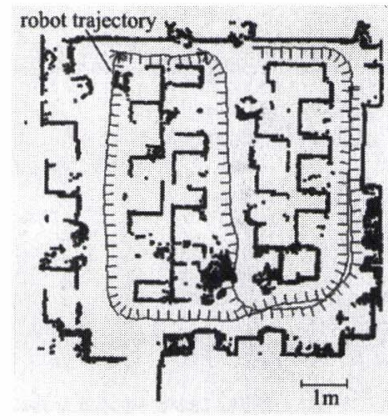

(b) Map by scan matching
Fig. 13 Experimental results of room map building
・ケース 2 (提案方式)

大域マッチングと 4 章で述べた詳細マッチングを行った. 遺伝的アルゴリズムにより式（6）の最適化を行った。遺伝 的アルゴリズムの繰り返し回数 $=5$, パーティクル数 $=10$ である。

・ケース 3(大域マッチングと ICP の併用)

大域マッチングと ICPによる詳細マッチングを行った。大 域マッチングで得られた各候補に対して，最急降下法によ り式（6）の最適化を行い，その中でスコア最良のものを採 用した。

定量評価のために，全スキャンに対する式（6）の合計值（残 差合計）を求めた，対象環境は，Fig. 13 および後出の Fig. 14, 15 で用いた 3 種類のスキャンデー夕である。スキャン数は，そ れぞれ，168 個，109 個，および，162 個である。Table 3 に 示す実験結果から，ケース 2 が最も残差合計が小さいことが分 かる. 4.2 節で述べたように，詳細マッチングの目的は，大域 マッチングで得られた複数の有力候補を保持しながら䛊差を最 小化することであるが，この実験から，そのマッチング精度は $\mathrm{ICP}$ と同等以上であることが分かる.

\section{5 大域スキャンマッチング}

大域スキャンマッチングの実験では，あらかじめ作成したマッ プに対して，別途収集したスキャンがどの程度正しくマッチン グするかを調べた。オドメトリ情報は使わず，マッチング範囲 も限定しない。また，マッチしたスキャンをマップに追加する ことはせず，すべて独立にマッチングを行った。

\section{(1) 廊下}

最初の実験は, Fig. 11 の廊下の右下の領域で実験した。マップ は, Fig. 11 と同じデータを用いて作成した。これを Fig. 14 (a) に示す。このスキャンは，ロボットが同図の矢印の方向に向かっ て走行して収集したものである。次に，別途，ロボットを順方 向と逆方向の 2 回走らせ，それぞ机でスキャンを収集して，そ のスキャンを用いて上記マップ上で大域スキャンマッチングを

Table 3 Total residuals of precise matching

\begin{tabular}{|l|r|r|r|}
\hline & corridor1 & room1 & room2 \\
\hline case 1 & 2146 & 2942 & 2810 \\
\hline case 2 & 2042 & 2702 & 2543 \\
\hline case 3 & 2058 & 2797 & 2580 \\
\hline
\end{tabular}

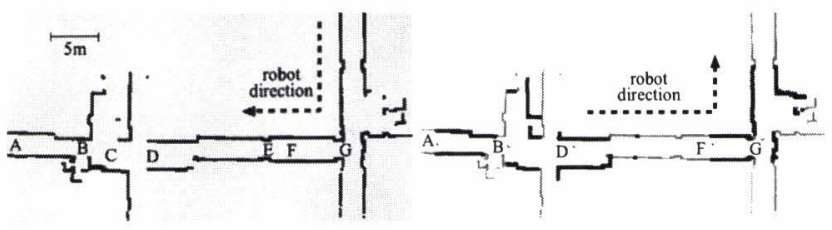

(a) Original map

(b) Global scan matching results

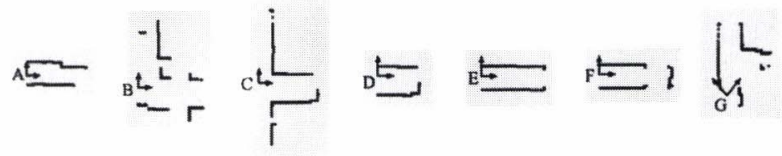

(c) Examples of scans used in global scan matching

Fig. 14 Experimental results of global scan matching (1) 
Table 4 Matching rate in global scan matching (1)

\begin{tabular}{|l|r|c|c|r|}
\hline & total & best & best five & fail \\
\hline same direction & 78 & $76(97.4 \%)$ & $78(100 \%)$ & 0 \\
\hline counter direction & 110 & $61(55.4 \%)$ & $75(68.1 \%)$ & 35 \\
\hline
\end{tabular}

行った。 その結果を Table 4 に示す。この表は, 全スキャン数 (total), スコア 1 位でマッチしたスキャン数 (best), スコア 1〜5位に含まれたスキャン数 (best five)，マッチングに失敗 したスキャン数 (fail) を示す。表から分かるように, 順方向で は極めてマッチング率は高い，スコア 1 位にならなかった 2 個 は, 二つの平行線から構成されるスキャン (Fig. 14 (c)Eとほほ 同型）であった。この二つのスキャンについては, 類似形状の 領域が多数存在するため, 他の領域とマッチングしたが, 正し い位置にもマッチしたので候補には含まれた。

一方, 逆方向のマッチング成功率は低い.これは, オクルージョ ンによって, 逆方向で収集したスキャンの形状とマップ形状が異 なるものとなるためである。この様子を Fig. 14 (b)，(c)に示す. Fig. 14 (b)では，見やすさのため, マップをグレーで, マッチし たスキャンを黒で示している. Fig. 14 (c)は, Fig. 14 (a)のA一 $\mathrm{G}$ 点において, 収集したスキャンである, 逆方向から測定した ため, Fig. 14 (a)のマップとは形状が異なる. Fig. 14(b)は,こ れらのスキャンを大域マッチングした結果である。スキャン A Gのうち, Cと E は正しくマッチしなかったので, Fig. 14 (b) には載せていない。それ以外は正しくマッチした。 スキャン形 状が一致しなくても類似していれば，高い頻度でマッチングに 成功している。

マッチングしなかったスキャンについて, 次のような傾向が あった。スキャン Cでは, マップ側には縦線に対応する部分が まったく存在しないため, 不一致部分が多すぎてマッチングに 失敗した。実際には，横線だけで対応する領域にランダムにマッ チした、スキャン E は，ほとんど平行線から成るため，廊下の 平行な領域に多数マッチングした，特に逆向きにマッチするこ とが多かった。

比較のため，APR を用いて同じ実験を行ったＡPRのプロ グラムは文献 [17] をもとに実装した。もとのAPRには詳細マッ チングに相当する部分はないが，提案方式と条件を同じにする ために，まず APRで大域候補抽出を行い，その後提案方式の 詳細マッチングを行った。 なお，提案方式では，参照スキャン はそれまで作成したマップであるが，APRでは，それまでに入 力した個々のスキャンである。

APRの実験結果は, 順方向では, スコア 1 位でマッチした スキャン数が 44 個, スコア 5 位以上でマッチしたスキャン数 が 45 個, 失敗が 33 個であった。失敗したものの多くは, ほと んど二つの平行線から構成されるスキャンであった，完全な平 行線でなく多少の起伏があるスキャンでも, APRで用いる特 徵点は得られないため, マッチングはできなかった。一方, 逆 方向では, スコア1位でマッチしたスキャン数が 6 個, スコア 5 位以上でマッチしたスキャン数が 6 個, 失敗が 104 個であっ た. 逆方向でオクルージョンが多いと, 使用可能な特徵点が激 減するため, 失敗率が高くなると考えられる。

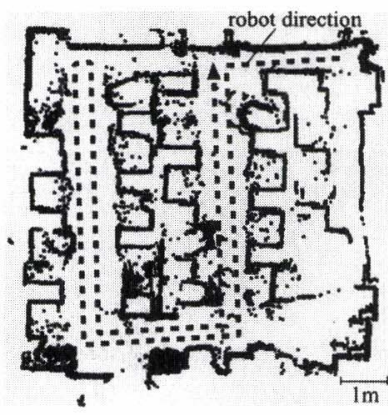

(a) Original map

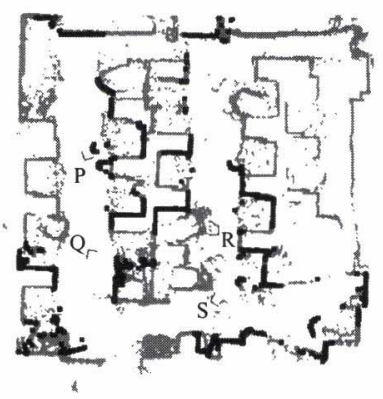

(b) Global scan matching results
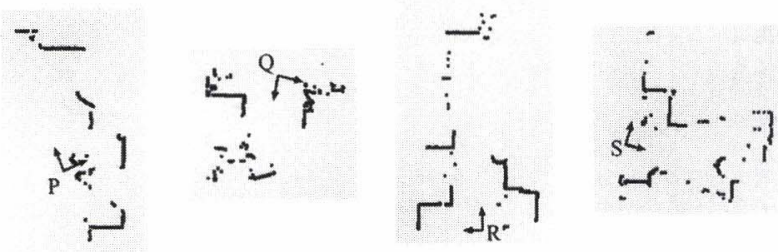

(c) Examples of scans used in global scan matching

Fig. 15 Experimental results of global scan matching (2)

Table 5 Matching rate in global scan matching (2)

\begin{tabular}{|l|r|c|c|r|}
\hline & total & best & best five & fail \\
\hline same-day scans & 100 & $96(96 \%)$ & $100(100 \%)$ & 0 \\
\hline another-day scans & 85 & $50(58.8 \%)$ & $78(91.7 \%)$ & 7 \\
\hline
\end{tabular}

\section{(2) 実験室}

実験室において大域スキャンマッチングの実験を行った。廊 下の実験から，ロボットを片方向だけ走らせて収集したスキャ ンからマップを作ると，それと逆方向に走行した場合のマッチ ング率が带いことが分かったので, この実験では, マップ作成 の際にロボット在而方向に走らせてオクルージョンがなるべく 少ないマップを作成した．Fig. 15 (a) に作成したマップを示す. なお，実験は，人間が数人椅子に座っている状態で行った。

マップ作成日と同じ日に別途収集したスキャンを用いてここ のマップ上で大域スキャンマッチングを行った、その結果を Table 5 上段に示す。マップ作成日と同じ日なので，環境変化は 少なく、マッチング率は非常によい。次に、マップ作成日の約 4ケ月前に収集したスキャンを用いて大域スキャンマッチングを 行った結果を Table 5 下段に示す。家具などの基本レイアウト は変わっていないが、ゴミ箱など動きやすい物体の位置が異な り，また，荷物や着席した人間の配置が異なる。このため，マッ チング率は落ちている。

ここでも APR との比較を行った. Table 5 上段のデー夕を 用いた場合，スコア 1 位でマッチしたスキャン数が 74 個，ス コア 5 位以上でマッチしたスキャン数が 74 個, 失敗が 26 個で あった。一方, Table 5 下段のデー夕を用いた場合, スコア 1 位でマッチしたスキャン数が 42 個，スコア 5 位以上でマッチ したスキャン数が 57 個, 失敗が 28 個であった.

この実験室では，スキャン形状が複雑なため，廊下よりも多 くの特徴点が得られ，APRのマッチング率はよくなっている. 
しかし, 形状が複雑な分, スキャンにはノイズ状の点群も多く含 まれ，不適切な特徵点が誤検出されやすくなる. 実装した APR プログラムでは点群サイズなどに基づいてノイズ除去を行って いるが，ノイズかどうかの判定は閾值に依存しており一般に難 しい，スキャンによっては，基本形状は単純だがノイズを多く 含むことがありうる。その場合，不適切な特徽点が相対的に多 くなり，マッチングに失敗しやすくなる。これに対して，本方 式は，多数のスキャン点をそのまま用いるため，ノイズによる 影響は相対的に小さくなり，安定したマッチングが実現できる.

\section{7. 考}

\section{察}

実験により，本方式が高いマッチング率で精度のよいマップ を構築でき，しかも，大域自己位置推定で利用可能なロボット 姿勢候補を提供できることを確認した。本方式は，廊下のよう に比較的単純な形状の環境にも，実験室のように複雑な形状の 環境にも適用できる。

本方式の問題点の一つは, 詳細マッチングにおいて乱数を用 いているため, 試行ごとにマッチング結果 (誤差) が多少変化 することである。こ㞦に対処するには，パーティクルフィル夕 の繰り返し回数を増やす，勾配法など再現性のある方法を用い る，などが考えられる。また，スキャンマッチングに䛊差分布 を導入し，その誤差を評価できるようにする方法も有効である。 これらの検討は今後の課題である.

もう一つの問題点は，あらゆるスキャンマッチング方式に共 通であるが，マッチング性能がスキャン形状に影響されること である．正しくマッチするかどうかは，二つのスキャンの合致 部分の大きさに依存する。良い形状のスキャンが得られる場合 は，本方式でほぼ100\%のマッチング率が得られる。しかし，来 環境では種々の要因によって，理想的なスキャンが得られない ことがある．以下に，考えられる問題を述べる。

(1) スキャン形状の歪み

ロボットの動きが急峻な場合，スキャンデータがぶれて，マッ チングに悪影響を及ほすことがある。一般に，多少の歪みがあっ てもマッチングは可能であるが，それによって位置誤差は増え る。また，歪みが大きくなれば失敗率が増える。このような歪 みは，頻度は少なくても，実環境では必ず起きるので，マッチ ング失敗からの復㷌機能は重要である。これは，一般には大域 自己位置推定により対処できる。

マッチング失敗が一過性であれば，大域自己位置推定を行わ なくても，復帰が可能である，上記実験でも，廊下での実験中 に操縦ミスでロボットが 1 回転スピンをしてしまい，その際の スキャン 1 個がマッチングできなかったが，その後のスキャン では現在のマッチング範囲内で正しくマッチングができ, 復帰 することができた。

（2）単純なスキャン形状による退化や多義性

上記実験では廊下に突起があったため問題なかったが，例え ば，凹凸のない長い廊下では，平行線だけからなるスキャンが 得られ，どの部分にもマッチングできてしまう。これは，数学 的に退化が起きているので，スキャンマッチングだけでは，本 質的に解決できない。、ロボットの自己位置推定だけが目的の場 合は，複雑な形状の場所に着いた時点で大域自己位置推定を行
えばよい.マップ構築の場合は，その区間のマップも作る必要 があるため，オドメトリなど他のセンサの併用が必要である.

（3）疎なスキャン

本方式は有向点を用いるため, 接線方向が安定してとれない ような形状には向かない. 例えば, 細いパイプのような曲率の小 さい曲線や細かいギザギザが多数を占めるような領域ではマッ チング精度が非常に悪くなる。本実験には含まれていないが， ガラス空に格子状の手すりが連続した渡り廊下を走行させた際 は，スキャンは手すりの細いパイプだけで構成され，マッチン グができなかった：どのくらい細かい形状まで対応できるかは， スキャン点の間隔や離散化サイズなどのパラメータに依存する. こ机はセンサの特性にも依存するが，適切なパラメー夕值に関 する詳細な分析は今後の課題である.

（4）環境形状の変化

物体の位置が変化すると，スキャン形状は変わる。一般に，不 変領域が大きくて変化部分が小さけ机ば，マッチングにはほと んど影響しない．上記廊下実験でも，通行人やドアの開閉など により，通行の前後でスキャン形状が変わることがあった。ド アは 3 筒所で開閉したが，そのうちの 1 回だけマッチングがず れて $200[\mathrm{~mm}]$ 程度の䛊差が生じた。それ以外は，ドアの開閉 は影響しなかった。また，同時に最大 3 人，のべ 14 人の通行 人とすれ違ったが，マッチングに影響はなかった。

ドアや通行人などの環境変化があってもマッチングができた のは， 5.1 節で述べたようにマッチング範囲を限定していたこ とも寄与している．環境形状が単純で，しかも，マッチング範 用が広い場合は，わずかな環境変化でもマッチングに影響を与 える可能性がある．環境変化や移動物体にきちんと対処するに は, マップの更新機能や移動物体の追跡機能が必要である.

(5) オクルージョンの影響

大域スキャンマッチングでは，オクルージョンによるスキャン 形状の変化によって，マッチング率が大きく影響される。実際， 6.5 節（1）の実験で，ロボットを逆向きに走らせた場合，入力 スキャンとマップの形状が大きく食い違い, ミスマッチが増え た.このことから，マップ構築時に，マップ内のオクルージョ ンをできるだけ減らしておくのが望ましい. マップ構築時のス キャンマッチングでは，マッチング範囲を限定できるので，才 クルージョンがあってもミスマッチを回避できる可能性が高い.

\section{8. まと め}

本稿では, 移動ロボット用の二次元スキャンマッチング方式を 提案し，マップ構築や大域自己位置推定への応用を示した。本 方式は，大域マッチングが可能で，しかも，単純な形状から曲 線を含む複雑な形状まで多様な環境形状に適用できるという特 長をもつ. 今後の課題として，スキャンマッチングに誤差分布 を導入し，マップ構築や大域自己位置推定を確率的に行うこと があげられる。

謝 辞 本研究は, 独立行政法人科学技術振興機構の戦略的 創造研究推進事業・個人型研究（さきがけ）により行われた。春 施に当たっては, 筑波大学油田信一教授, 坪内孝司教授に, 研 究環境を提供していただいた。ここに感謝いたします。 


\section{参 考 文 献}

[1] P.J. Besl and N.D. Mckay: "A Method of Registration of 3D Shapes," IEEE Trans. on PAMI, vol.14, no.2, pp.239-256, 1992.

[2] P. Biber and W. Straßer: "The Normal Distributions Transform: A New Approach to Laser Scan Matching," Proc. of IROS2003, pp. 2743-2748, 2003.

[3] J.A. Castellanos, J.M.M. Montiel, J. Neira and J.D. Tardos: "The SPmap: A Probabilistic Framework for Simultaneous Localization and Map Building," Trans. on Robotics and Automation, vol.15, no.5, pp.948-952, Oct. 1999

[4] D. Fox, W. Burgard, F. Dellaert and S. Thrun: "Monte Carlo Localization: Efficient Position Estimation for Mobile Robots," Proc. of AAAI'99, pp.343-349, 1999.

[5] W.E.L. Grimson: Object Recognition by Computer: The Role of Geometric Constraints. MIT Press, 1990.

[6] J.S. Gutmann, T. Weigel and B. Nebel: "Fast, Accurate, and Robust Self-Localization in Polygonal Environments," Proc. of IROS'99, pp.1412-1419, 1999.

[ 7 ] P. Jensfelt and S. Kristensen: "Active Global Localization for a Mobile Robot Using Multiple Hypothesis Tracking," IEEE Trans. on Robotics and Automation, vol.17, no.5, Oct. 2001.

[8] A.E. Johnson and M. Hebert: "Efficient Multiple Model Recognition in Cluttered 3-D Scenes," Proc. of CVPR'98, pp.671$677,1998$.

[9] Y. Lamdan and H.J. Wolfson: "Geometric Hashing: A General and Efficient Model-based Recognition Scheme," Proc. of ICCV'88, pp.238-249, 1988.

[10] J.J. Leonard and H.F. Durrant-Whyte: "Simultaneous Map Building and Localization for an Autonomous Mobile Robot,"
Proc. of IROS'91, pp.1442-1447, 1991.

[11] D.G. Lowe: "Object Recognition from Local Scale-Invariant Features," Proc. of ICCV, pp.1150-1157, 1999.

[12] F. Lu and E. Milios: "Robot Pose Estimation in Unknown Environments by Matching 2D Range Scans," J. of Intelligent and Robotic Systems, vol.18, pp.249-275, 1997.

[13] M. Montemerlo, S. Thrun, D. Koller and B. Wegbreit: "FastSLAM: A Factored Solution to the Simultaneous Localization and Mapping Problem," Proc of AAAI2002, pp.593-598, 2002.

[14] C.F. Olson: "Time and Space Efficient Pose Clustering," Technical Report UCB//CSD-93-755, 1993.

[15] S. Thrun: "Robotic Mapping: A Survey," CMU-CS-02-111, Feb. 2002 .

[16] 友納, 油田：“不正確さを許すマップにおける移動ロボットの自己位 置推定”, 日本ロボット学会誌, vol.20, no.4, pp.425-436, 2002.

[17] J. Weber, K.W. Jorg and E.V. Puttkamer: "APR-Global Scan Matching Using Anchor Point Relationships," Proc. of IAS-6, pp.471-478, 2000.

[18] Z. Zhang: "Iterative Point Matching for Registration of FreeForm Curves," INRIA Technical Report RR-1658, 1992.

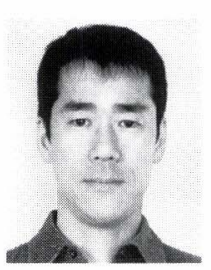

友納正裕 (Masahiro Tomono)

1960 年 5 月 10 日生. 1985 年東京大学大学院丁学 系研究科修上課程修了. 同年 NEC 入社. 1999 年退 社. 2002 年筑波大学大学院博士課程修了. 2002 2006 年, 科学技術振興機構さきがけ研究者. 2006 年，東洋大学．現在に至る。ロボットの環境認識， 行動制御, ソフトウェアアーキテクチャなどに興味 を持つ、情報処理学会, IEEEの会員. (日本ロボット学会正会員) 